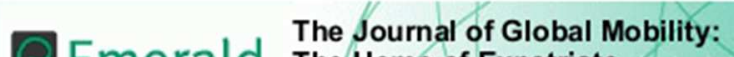 \\ Emerald The Home of Expatriate \\ Management Research
}

\section{Long-term assignment reward (dis)satisfaction outcomes: hearing women's voices}

\begin{tabular}{|r|l|}
\hline Journal: & Journal of Global Mobility \\
\hline Manuscript ID & JGM-04-2015-0011.R4 \\
\hline Manuscript Type: & Research Paper \\
\hline Keywords: & $\begin{array}{l}\text { Expatriates, Women, Gender, Organisational justice, Balance sheet, Oil } \\
\text { and gas industry, Reward }\end{array}$ \\
\hline \multicolumn{2}{|l}{} \\
\hline
\end{tabular}

SCHOLARONE ${ }^{\text {Ix }}$

Manuscripts 


\section{Long-term assignment reward (dis)satisfaction outcomes: hearing women's} voices

\section{Abstract \\ Purpose}

Drawing upon compensating differentials, equity theory and the psychological contract, women's voices illustrate how organisational policy dissemination, implementation and change can lead to unintended assignee dissatisfaction with reward. Implications arise for organisational justice which can affect women's future expatriation decisions.

\section{Design/methodology/approach}

A qualitative case study methodology was employed. Reward policies for long-term international assignments were analysed. In-depth semi-structured interviews were conducted confidentially with 21 female long-term assignees selected using stratified sampling, and with two managers responsible for international reward policy design/implementation.

\section{Findings}

Policy transparency is required. Women perceive inequity when allowances based on grade are distorted by family status. Women in dual career/co-working couples expect reward to reflect their expatriate status. Reward inequity is reported linked to specific home/host country transfers. Policy change reducing housing and children's education are major causes of reward dissatisfaction.

\section{Research limitations}


This case study research was cross-sectional and set within one industry. It addressed reward outcomes only for long-term international assignments from the perspectives of women who had accepted expatriation in two oil and gas firms.

\section{Practical implications}

Reward policy should be transparent. Practitioners might consider the inter-relationship between policy elements depending on grade and accompanied status, location pairings, and the effects of policy content delivery to dual career/co-working couples.

\section{Originality/value}

This paper advances the field of international assignment reward by examining compensating differentials, equity and the psychological contract and takes these forward via implications for organisational justice. It identifies reward elements that support women's expatriation and address their low share of expatriate roles, thereby fostering gender diversity. Future research themes are presented.

\section{Introduction}

Mindful of women's relatively low international assignment representation over the years combined with organisational desire to increase expatriate gender diversity (Altman and Shortland, 2008), this article aims to identify relevant theory and provide a practical contribution to help foster women's expatriation through the analysis of the content and communication of organisational long-term assignment reward policy. To this end it examines how organisational dissemination of expatriate 'balance sheet' policy and its practical implementation can affect assignee satisfaction, which has implications for women's future expatriate participation decisions. It takes as its focus the reward policy elements which female expatriates in the oil and gas exploration and production industry (a 
traditionally male-dominated and expatriate-heavy industry) report as crucial to their longterm assignment acceptance. It also examines policy changes and how these affect women assignees. These issues are illustrated through the first-hand perspectives of these expatriates themselves: with women's voices.

While the extant literature acknowledges that money is not the primary motivator for assignment acceptance (Pate and Scullion, 2010; McNulty, 2014), rather career and family considerations and job development are most typically key drivers behind employees' expatriation decisions (Dickmann, Doherty, Mills and Brewster, 2008; Hippler, 2009), this does not negate the importance of reward policy and practice for those undertaking global careers (Suutari, Tornikoski and Mäkelä, 2012). Expatriates expect their compensation and benefits to be fair and equitable and for their families to reap some benefits financially (Welch, 1994). The most frequently mentioned elements of relevance to the assignment participation decision are financial in nature (salary, housing, location bonus, flights home and children's education), with salary and housing most likely to result in assignment refusal if they are not addressed appropriately (Warneke and Schneider, 2011). Cost of living payments and healthcare are also cited as crucial (Sims and Schraeder, 2005) and assistance given to spouses also influences willingness to go (Borstorff, Harris, Feild and Giles, 1997). The top five reward elements that are causes of dissatisfaction once on assignment are identified as being the total salary, travel costs, insurance benefits, repatriation, and spouserelated issues (Suutari and Tornikoski, 2001).

Women have traditionally held only a small share of expatriate roles. Early studies, such as those of Adler (1984) indicate that women comprised a mere $3 \%$ of expatriates at that time. Over the years their employment in organisational expatriate positions has gradually increased but it still falls far short of men's (Shortland, 2014a). Today, women only hold 
around $19 \%$ of organisation-assigned expatriate roles across industry (Brookfield Global Relocation Services, 2015).

With respect to women, we know that career outcomes surpass money as their primary motivator for assignment acceptance but that the remuneration potential to be gained through working abroad (Tharenou, 2014) and the financial attraction of expatriate packages (Shortland, 2015) do play a part in their decision-making. However, we do not know how women view the importance of specific elements of expatriate reward, how these are communicated to them, and their effects on women's long-term assignment participation and upon their relationship with their employers.

This qualitative research study set out to address the following question: how is women's long-term assignment participation affected by international assignment reward policy and its practical implementation? The study was set within the theoretical frameworks of compensating differentials (Rosen, 1986), equity (Adams, 1963) and the psychological contract (Rousseau, 1989). This article provides a theoretical contribution to the field of expatriate compensation by demonstrating implications for organisational justice and by presenting themes for future research. It also makes a practical contribution through the identification of employer actions with respect to reward policy communication and implementation that can enhance women's assignment participation.

\section{Literature review}

The value of expatriation and of expatriate gender diversity

Expatriation is known to provide international experience and competency development for individuals, and expatriates generally perceive career opportunities will flow from their assignments. While there is some evidence to suggest that despite assignees' positive 
perceptions, working abroad can reduce contacts that lead to new work opportunities (Benson and Pattie, 2008), expatriation is generally considered to result in career growth and leadership opportunities (Caligiuri and Colakoglu, 2007; Carpenter, Sanders and Gregersen, 2001; Dickmann and Baruch, 2011; Orser and Leck, 2010; Thomas, Lazarova and Inkson, 2005). Organisations rely on assigning expatriates to fill skills gaps, train and develop local people and disseminate corporate culture and values. They also use expatriation to build their global talent pool (Haslberger and Brewster, 2009; Hocking, Brown and Harzing, 2004; McNulty and Brice, 2014). Hence, encouraging talented individuals to accept an international assignment and ensuring that they remain motivated while undertaking it are critical to organisational success in the global arena.

Researchers have examined many aspects of women's expatriation in an attempt to explain their under-representation. These have included: women's choices, dual career and family constraints on their international mobility; organisational decision-making and potentially biased selection processes; societal cultural effects and often false negative perceptions of how host nationals will receive women affecting employer decisions to deploy them; and institutional effects such as gendered labour market structures and organisational standardisation of policy, practice and role professionalization that reinforce women's minority position (Shortland, 2014a). Set against women's under-representation as organisation-assigned expatriates, women have progressed their international careers via frequent travel and home country-based roles with international responsibilities to gain exposure to global work opportunities (Hutchings, Lirio and Metcalfe, 2012). However, these do not provide the depth of cultural experience and development found in undertaking longterm international postings (Adler and Bartholomew, 1992). Women have also gained positive career experiences through self-initiated expatriation (Muir, Wallace and McMurray, 2014). It is notable that women's participation in self-initiated expatriation equals men's 
possibly because it provides career opportunities that women are unable to access via organisation-assigned expatriation (Tharenou, 2009). Nonetheless, organisation-assigned expatriation using long-term assignments is known to be the primary business driver of global leadership through planned career development (PricewaterhouseCoopers/Cranfield, 2006).

The current picture with respect to organisation-assigned expatriate gender diversity thus not only hinders women's career progression but also constrains employers' efforts to address global talent requirements. This is especially significant as women not only value the chance to work abroad (Gripenberg, Niemistö and Alapeteri, 2013), but are very successful when undertaking expatriation, even surpassing men in terms of assignment outcomes (Adler, 1987; Cole and McNulty, 2011; Dallalfar and Movahedi, 1996; Harrison and Michailova, 2012; Tung, 2004; Varma, Toh and Budhwar, 2006). Organisational interventions to increase expatriate gender diversity are thus valuable to employers and women alike.

The role of reward policy in international assignment acceptance

To understand and predict the effects of organisational decisions on expatriate reward policies on assignment acceptance, satisfaction and motivation outcomes, we need theory to guide us. Regrettably, there is overall paucity in theory, and empirical research is underdeveloped in relation to expatriate compensation (Bonache, 2006; Harvey and Moeller, 2009). Nonetheless, we do have some studies and theoretical frameworks that are helpful and can be applied to research into women's perceptions of international rewards and how these influence their assignment participation. For example, compensating differentials theory (Rosen, 1986) helps us to understand the nature of the differential between expatriate reward and home-based pay to assess the added value that the 'balance sheet' approach to expatriate compensation brings to long-term assignment compensation. Equity theory (Adams, 1963) 
assists us with our understanding of whether, and if so how, individuals perceive these reward packages as fair, while Rousseau's (1989) theory of the psychological contract helps us to understand assignees' relationships with their employers and their potential assignment participation decisions based on their perceptions of reward equity.

Compensating differentials theory posits that additional income is required if a worker is to accept a job that is deemed undesirable relative to other jobs that he or she might carry out (Rosen, 1986). This persistent wage difference is known as a compensating differential and acts to encourage or motivate the individual to take up the job. Although organisationassigned expatriation provides attractive career prospects (Dickmann and Baruch, 2011), having to relocate internationally and undertake work in a different country (potentially in an insecure or remote location away from family and friends) suggests that additional financial and non-financial compensation/benefits would be required. If these are not addressed via a compensating differential, this will most likely jeopardise assignment satisfaction and commitment. Thus, international assignment policies typically provide elements to address the special circumstances that relate to expatriates' lives.

The philosophy of the balance sheet approach is to keep expatriates 'whole' which means they neither lose nor gain financially from their assignment (Oemig, 1999). Their salaries are aligned with home country peers with additional allowances such as housing, cost of living, children's education, foreign service and 'hardship' premiums and so on added on (Bonache, 2006; Dowling and Welch, 2004; Perkins and Shortland, 2006; Tarique, Briscoe and Schuler, 2016). These additions generate a compensating differential and thereby encourage expatriates to take an assignment. The quid pro quo is that this differential can create perceptions of unfairness amongst host-country nationals (Bonache, Sanchez and Zárraga-Oberty, 2009). In addition, the compensating differential conflicts with objectives such as controlling expatriate costs and the ability to repatriate assignees (Bonache, 2006). 
Anker (2001) applies compensating differentials theory to women's work and, recognising their acknowledgement of the need to combine or interrupt their careers with childbearing, suggests that women 'prefer' occupations that provide good working conditions and/or to take some of their 'pay' as fringe benefits. So, following this assertion, for women undertaking long-term expatriation, this would suggest they would particularly value benefits such as work-life balance arrangements and family assistance, placing greater emphasis on these policy aspects rather than on base salary, pay for performance, bonuses and other monetary elements. Although research is limited, Scott et al. (2015) find in their study of graduate students' pay preferences that men prefer performance-based (variable) pay over women but that there are no significant differences between men and women's preferences for bonuses, pay transparency and pay differences based on individual skills/capability. Research into how female expatriates view reward elements is thus a useful contribution to understanding their role in supporting women's expatriation.

Equity theory (Adams, 1963) helps us to understand the effects of the application and dissemination of international reward policy content and changes made to it by organisations on women's perceptions of fair treatment. This leads us to consider how policy implementation may affect women's psychological contracts (Rousseau, 1989) to help us interpret organisational reward practice in the context of the assignee-employer relationship and thereby identify implications for women's international mobility.

Adams' equity theory (1963) is more precisely about inequity. Adams states that pay leads to employee satisfaction only to the extent that it is viewed as fair and equitable. When an exchange takes place (for example between an assignee and the organisation), there is the potential for either or both parties to view the exchange as inequitable, taking into account the inputs made by each side to the relationship. The value of the input depends, for instance, on perceptions of relevance to the exchange. Also involved in the exchange are outcomes, such 
as rewards received by assignees for their expatriate duties. The value of the outcomes is also perceived, for example, in terms of relevance. Thus, for example, certain aspects of the expatriate package, such as payment for children's education, may have no relevance to childless assignees. This can affect an individual's perceptions of the equitable nature of expatriate rewards because Adams (1963) proposes that employees compare themselves with co-workers and it is this social comparison of inputs and outcomes in the exchange relationship that can lead to perceptions of inequity. In the case of expatriates such comparisons can be made with local nationals and/or other expatriates in their work location, other organisational locations of operation and indeed other firms. With so many referents, perceived inequity becomes highly likely and assignee dissatisfaction with reward packages a strong possibility (Bonache, 2006).

Adams (1963) notes that to understand and predict when an individual will perceive inequity under given conditions of inputs and outcomes, the employer would need to know about the individual's values. While this is potentially possible at a cultural level drawing upon expected attitudes and beliefs, this becomes very difficult at an individual level. If an employee perceives inequity this creates tension which can lead, for example, to individuals increasing or decreasing their inputs (e.g. effort) and/or outcomes (e.g. seeking changes to pay). Individuals may also leave their organisations as a more radical means of reacting to inequity.

Expatriate satisfaction with their reward packages is a crucial issue to organisations if they are to develop and maintain productive employment relationships with - and not lose these highly paid and valuable individuals (Bonache, 2006). Hence, it is important that employers address policy design and its implementation in such a way as to reduce perceptions of inequity. This links closely to the psychological contract which reflects individuals' beliefs about perceived promises made to them by their employers in return for 
reciprocal actions (Rousseau, 1989). This contract underpins the employment relationship (Guest and Conway, 2002; Rousseau, 1995). If organisations do not meet their perceived obligations in a way that employees expect, the employment relationship is damaged through loss of employee trust. The breach of an employee's psychological contract can lead to frustration, disappointment and anger. That said, the psychological contract is subjective and thus how employees perceive any organisational explanation for a breach determines the level of damage to their psychological contract and the actions they may take as a result (Rousseau, 1989).

Contracts within organisations vary in their nature. As Guzzo, Noonan and Elron (1994) explain transactional contracts address specific issues, are narrow in scope and can be limited in time, whereas relational contracts are wider, less structured and change over time. They point out that relational contracts can have transactional elements within them which can be monetarised. Expatriates are particularly sensitive to employer actions as relocating abroad affects both the individuals themselves and also their family members and home lives. For expatriates, relational aspects including employer support for family life are encapsulated within international assignment reward policies as these typically encompass a wide range of benefits that address family needs such as housing, children's education, home leave, medical care, security services and so on. While these policy aspects do have a monetary value, they also have a key function in supporting assignees and their families outside of the context of direct employment in the job. As such, how employers manage these reward elements, which although ostensibly transactional in form have significant relational implications, is highly significant to assignment satisfaction. The management of expatriate and family mobility is therefore critical to levels of trust, organisational commitment and turnover intentions (Pate and Scullion, 2010). Besides a focus on the expatriation and repatriation points (Haslberger and Brewster, 2009), damage to assignees' psychological contracts can also lead to turnover 
while on assignment (McNulty, De Cieri and Hutchings, 2013). Thus, organisations need to pay attention to both transactional and relational contracts to encourage assignment acceptance, and maintain the employment relationship during the assignment and on return. The intent behind organisational actions is crucial to assignee engagement and motivation (McNulty, 2014).

Guest and Conway (2002) draw attention to the need for clear and consistent personal, job-related and recruitment-related communication and reinforcing the role of Human Resources (HR) practitioners in ensuring this takes place. Tornikoski's (2011a and b) research into expatriates' commitment and attachment to their organisations gives us some key insights set within the context of total reward packages and the psychological contract. It is notable that she finds tangible rewards assist in attracting expatriates to accept certain assignments but are inadequate for assignee retention. Employers need to foster social exchange relationships with expatriates before, during and after their assignments to maintain their trust and commitment. Taking this forward, this study examines the reward elements of importance to female assignees and how these are implemented and communicated to explore their effects on women's expatriate participation.

\section{Methodology}

This section outlines the industry context and research design, the case study context and the methods employed in data collection.

\section{Industry context and research design}

The oil and gas exploration and production sector is well-known for the origination and development of the 'balance sheet' approach to expatriate reward (Chesters, 1998), one of the oldest and most commonly used expatriate pay systems worldwide (Perkins and White, 2011; Sims and Schraeder, 2005). This industry is also known to provide generous expatriate 
compensation and benefits (IDS, 2002) reflecting rising worldwide demand for oil and gas and the sector's increasing reliance on expatriation to service this (Brookfield Global Relocation Services, 2009). In addition, it is a particularly interesting industry in which to examine reward policy, especially given many of its locations of operation are in remote, difficult and dangerous locations, with some affected by major political uprisings (Markus, 2015) leading to high levels of financial recompense. The industry also experiences waxing and waning fortunes as oil and gas prices fluctuate, for example as recent extensive and successful shale exploitation in the USA has resulted in depression of world oil prices (Johnson, 2015). It is therefore a relevant industry in which to examine the effects of reward policy changes when these are implemented by employers. With respect to gender diversity, it is notable that in sectors that deploy the largest volumes of expatriates - such as oil exploration, engineering and mining (ORC Worldwide, 2007; Richardson, McKenna and Dickie, 2014) - women's share of expatriation is considerably lower than the all-industry average: at approximately 7-10\% (ORC Worldwide, 2007; Shortland, 2014b). Oil and gas exploration and production therefore presents a highly relevant sector to study the influence of reward policy on women's expatriate participation.

This study formed one strand of a major project on female expatriation conducted in two firms in the oil and gas exploration and production industry. Given the exploratory nature of this research, with its objective to clarify our understanding of whether - and if so how women's long-term expatriation may be affected by organisational reward policies, a case study research design was employed. Case study research is particularly appropriate in researching new topics (Eisenhardt, 1989) and, as Yin (2009) explains, case studies provide a rich understanding of context. Case study research also enables the use of multiple sources of evidence and data collection techniques. Thus, a case study design was considered to have the 
potential to address questions such as 'why' and explain 'how' reward may affect women's long-term assignment participation.

In this study, a triangulated, in-depth, qualitative research design was employed drawing upon independent data sources (Saunders, Lewis and Thornhill, 2009). These comprised: analysis of organisational policy on long-term international assignment reward; confidential in-depth, semi-structured interviews with female assignees undertaking longterm assignments; and in-depth, semi-structured interviews with the International Assignments (IA) Managers in each firm, held privately and separately from the assignee interviews. These IA specialists were responsible for long-term international assignment reward policy design and its practical implementation. The semi-structured interview questions used in this study were framed by compensating differentials and perceived equity considerations.

\section{Case study context}

Company A, headquartered in North America, employed approximately 12,000 people. It had operations in 20 countries. Expatriates working in exploration and production comprised 3\% of the workforce. There were 27 women expatriates ( $8 \%$ of the expatriate population) working in nine different countries. Eighteen women were undertaking long-term assignments based in seven countries. The remainder were on short-term, rotational or extended transfers.

Company B, headquartered in Western Europe, employed around 6,000 people. Its operations were based in 27 countries. Its exploration and production expatriate population comprised $10 \%$ of the workforce. It employed 66 female expatriates $(11 \%$ of its expatriate population) working in 18 countries. Forty-seven women were undertaking long-term 
assignments based in 17 countries. The remainder were on short-term, graduate trainee or rotational assignments.

\section{Data collection and analysis}

For the purpose of this part of the oil and gas female expatriate project, the case study firms both granted access to their international long-term assignment balance-sheet reward policies. They also gave access to the two specialist IA Managers (one in each organisation) who designed and implemented these and to the female expatriate policy recipients. Access to line managers and male expatriates was not given due to time and resource constraints. All 65 female long-term assignees were contacted by the IA Managers to request their participation in the research; 51 agreed to take part - 14 from Company A and 37 from Company B. Background data were supplied by the IA Managers in relation to the profile of the research participants. From these 51 women, 21 (seven in Company A and 14 in Company B) were selected using stratified sampling (Collis and Hussey, 2009) to be interviewed in-depth. This ensured appropriate representation taking into account assignment experience, home and host regions, accompanying family and assignment type. Table 1 sets out the profile of female expatriates interviewed. Pseudonyms are used here and throughout the paper. Confidentiality was assured and hence the data are presented by region rather than specific country and personal details such as ages of children are not reported. The majority of the women interviewed were married or partnered, with accompanying children. The most prevalent sending location was Western Europe. One-third of the women had relocated to East or Central Asia.

The balance-sheet policies in both organisations were read carefully. A note was made of each compensation and benefits component therein and these are summarised for each firm in Table 2. Company A had two separate policies addressing long-term 
assignments (one covering assignments to Europe and North America, the other covering other locations) while Company B had one world-wide policy. Policy content for both firms was standard for the industry.

- Tables 1 and 2 here -

The semi-structured interviews carried out with the 21 women assignees were conducted either by telephone if the woman was abroad or face-to-face if she was in the UK (on vacation or on business). Regardless of their whereabouts, all of the women assignees were asked the same questions following the assignee interview schedule given in the Appendix. Interviews were conducted confidentially in a private room and took, on average, between $60-90$ minutes. They were taped and transcribed with permission. The interviews aimed to gain insight as to why women viewed particular reward policy elements as crucial to their assignment acceptance. They also explored the importance of policy transparency, its dissemination and the effects of policy changes that had either taken place or were being introduced on women's expatriate participation. Interviews were conducted separately with the IA specialists, one in each firm. Conducted face-to-face, confidentially in a private room, each lasted 90 minutes and again were taped and transcribed with permission. These focused on policy implementation, development and change, following the IA staff interview schedule given in the Appendix.

All interview data were transcribed, coded and analysed using NVivo 8. The coding formed the underpinning to a template analysis (King, 2004). The transcripts were analysed using policy elements as the key themes. Issues identified were then grouped and aligned to the research questions. Analysis demonstrated consensus and difference between written policy, its practical implementation, and assignee experience. Emergent themes were identified and highlighted. As Yin (2009) notes such rival explanations help to support 
internal research validity. Contrasting company contexts and reward approaches were examined with representative quotations selected, thereby drawing upon the rich data to provide insights into the effects of international reward on female expatriates' long-term assignment participation.

\section{Findings}

This section highlights the reward policy elements that women assignees identified as crucial to their long-term assignment participation. It then reports on how policy dissemination and implementation affected their satisfaction with assignment rewards, and the effects on their relationship with their employer and future expatriation decisions. The findings are framed by compensating differentials (Rosen, 1986), equity theory (Adams, 1963) and the psychological contract (Rousseau, 1989).

\section{Reward elements critical to women's long-term assignment participation}

Aligned with the principle of compensating differentials (Rosen, 1986), the female assignees in both firms expected to receive significant compensation in recognition of the demands placed upon them and their families as a result of expatriating abroad:

"I guess there are only three reasons you go on an international assignment or posting. One is work, which can be more interesting. Two is to experience life in another country and without doubt ... the cash to do it because at the end of the day you forfeit an awful lot by leaving." (Izzy, Caribbean)

All assignees interviewed placed a high degree of importance on receiving an appropriate housing allowance that enabled them to live to a standard commensurate with their expatriate status. If housing was considered inappropriate it would preclude assignment 
acceptance ( “...the main thing... which would really mean whether you accept, or don't, is ... housing." Esther, Western Europe).

The other main financial policy element identified as highly important to women's long-term assignment acceptance was the Foreign Service Premium (FSP). This provided a financial 'uplift' to salary, calculated as a percentage of basic pay, with the level determined by the difficulty posed by the host location:

"It is the whole package. Getting free accommodation and getting your bills paid is enormously useful as well as we get a lot of free flights. And we get an uplift here in (West Africa), and it is particularly good." (Karen, West Africa).

“Financially, I don't think I would be interested in taking an assignment ... if I didn't have a tax-free uplift or some kind of financial reward ... coupled with the fact you get free accommodation." (Linda, Australasia)

The women assignees also identified the Cost of Living Allowance (COLA) paid when assignees move to locations where goods and services were more expensive as another crucial element that was required to be addressed before assignment acceptance. ("I need to make sure that I can live with that amount of that money that I'm going to get." Gina, North America). Mothers placed particular emphasis on children's education allowances if they were to accept a long-term international assignment.

\section{Policy transparency, dissemination and implementation}

Although the long-term assignment policy content was similar in both of the two case study firms (Table 2), there was a clear difference in approach in relation to its transparency and dissemination. In the North American headquartered Company A, the policy was not published and the terms were not made readily available even when an assignment role was 
offered. Company A's IA manager reported that her team tried to be "strict with the policy". The team's aim was to accommodate requests as far as possible within existing policy on a case-by-case basis, tailoring as necessary ("if it's not going to cause everybody to say I want that as well, then we will look at it favourably. But if ... I give it to you, I have to give it to everybody else ... we have to adhere to policy ... and so we like to feel that we are flexible, but within the policy").

Although Company A's HR team attempted to manage policy application flexibly with good intentions but within their known parameters, the female expatriates were unhappy with this lack of transparency. They said that it hindered their participation decision. This seemed to be particularly notable for those women relocating to East Asia:

"Our expat policies and our assignment terms and conditions are not particularly visible within the corporation ... they are not available publicly ... okay, it is nice being offered the job, but I want to know what level of support I am going to get, I want to know what that uplift is that you are talking about, I want to know what level of housing I'm going to get and what that is going to get me ... I want to know how my family is going to be treated ... until you see that package put together in front of you, you can't make a full decision." (Di, East Asia)

“... you have a discussion about the assignment and then it is offered ... and they seemed to be surprised when you ask about the terms, as if you would just accept the role before you understood what the terms were ... It is almost like you are expected to make it on trust." (Abby, East Asia)

"I didn't get that ... booklet until I was over here ... and someone there said there's a booklet, a document, and I said 'what!' And they said 'well, I don't know if I'm 
supposed to have it ... I'll give it to you but don't tell anybody I gave it to you'. Well it is crazy! We want to know the policy." (Fiona, East Asia)

In the Western European headquartered Company B, international assignment reward policies were posted on the intranet and issued on request. The IA manager noted that officially, the policy was "applied strictly" with an exceptions management process in operation to handle "special requests". However, at local level line managers were conscious of "the tight resources pool and the fact that they all know their market value" and so accommodated "excess demands ... 'to keep them sweet"' and, as a result, interpretation of policy was “not transparent”.

Company B's assignees liked the ready availability of the policy, but they confirmed that provision of certain elements was still subject to request:

"There is a copy of the policy on the intranet ... you will know the key requirements. Most of the stuff, I think is clear, but ... I know there were one or two things that you could have had this or that. I wasn't aware but ... (if) you ask a question, then you get an answer." (Xanthe, West Africa)

\begin{abstract}
Aligned with their IA manager, the women reported that reward policy could be subject to negotiation or local interpretation. This effectively undermined the intended transparency:

“Well, I don't know if interpretation is the right word, but they will have different housing budgets and you arrive and they say, you can't have that because of this, that and the other and you are not allowed the car because of this, that and the other and quite often they don't necessarily tell you the truth and then when you talk to lots of other expats, the goalposts are continually changing ... you are very much at the mercy of what they are interpreting the policy to be at that point." (Izzy, Caribbean)
\end{abstract}


“... this is ... still lacking and they have got their standard procedures that they want to stick to, but they are not basically, because then when you later find out several colleagues are being paid in (currency) without being related to that contract." (Nina, Middle East)

\section{Inequity in policy implementation}

Even when the international assignment reward policy was applied as written, the delivery of its elements had the potential to create inequity and dissatisfaction in both firms. For example, housing allowances were based upon salary grade. In practice, when the policy was implemented, married/partnered assignees and those with children received accommodation commensurate with their family size which was perceived as far better than that received by similar and higher graded individuals who had undertaken expatriation on single status:

\section{"I am ... a high (grade) level person. I am performing the same job as any people} who have got, say, a husband and child, or a wife, and ... even though they are on the same ... salary level as me at the same grade, the housing that they are afforded by the company ... is of a completely different quality ... I have fought this tooth and nail when I got out here, because the delta between the two was ridiculous." (Linda, Australasia)

This quotation demonstrates that expatriates can misinterpret policy intention resulting in damage to their relationship with their employer. Even if policy detail is readily available, if the rationale linking allowances to family status is not explained clearly by the organisation, as in Linda's case, perceptions of inequity arise. As a consequence, assignee satisfaction with the reward package is likely to be jeopardised and, as equity theory (Adams, 1963 ) predicts, perceived inequity vis-à-vis expatriate colleagues may generate discontent. 
Further examples of perceived unfairness concerned the application of salary uplifts such as the Foreign Service Premium (FSP). The FSP typically compensates for 'hardship' or difficulties in living conditions with the highest premiums paid in dangerous places. The IA Managers understood that FSPs paid to expatriates might suggest erroneously that the organisation valued assignees more highly than locals ("what are we actually saying to those local staff about what we think about their home?" IA Manager, Company B). However, the IA Managers had not anticipated how expatriates might interpret and react to the location differentials set out in policy, their resulting dissatisfaction with reward outcomes flowing from home/host country pairings, or the detrimental message that the policy sent on how employee diversity generally was valued. The expatriates reported that FSPs calculated on home/host country pairings led to a perception that expatriates from different home countries were valued differentially by their firms:

"So let's say we acknowledge that (West Africa) is a difficult place, it is dangerous and so on, (but) to say that somebody who comes from the (Western Europe) salary base is entitled to $60 \%$... to say that the actual uplift that you get ... depends on whether you come from a developed country or not, I think this is unfortunate ... You have policies about valuing your people and respect and corporate principles and so how can you look someone in the face and say it is less dangerous for you in (West African city) than for me? There is something wrong about the message." (Val, North America)

The expatriates also reported that FSPs calculated on an expatriate home/host country matrix basis resulted in unfair financial consequences for them depending on their sending location:

"All the expatriate allowances to developed countries (are) 10\%. So if I went from (Caribbean) ... to (Western Europe) I would get an uplift of 10\%, and this is a 
relatively expensive place, whereas, if somebody from (Western Europe) went to (Caribbean) and really live like a king ... you can have a gardener, a driver, a maid, you know what I mean if you are getting a 25\% uplift". (Val, North America)

When policy elements are misunderstood this can lead to dissatisfaction and affect future expatriation acceptance. Val erroneously related the payment of the FSP to living costs, whereas these would normally be addressed via the Cost of Living Allowance (COLA). Interestingly, Company B had a peer equity allowance within its international assignment reward policy. This aimed to compensate long-term assignees who were relocated from low salary economies to countries where local peers were paid higher base salaries. Val did not receive this, raising further questions about transparency, explanation and communication of policy content and intent. As expatriate careers that involve relocating from developing to developed economies increase, so does the likelihood that inequitable reward differentials will flow from non-traditional home/host pairings, highlighting the need for employer action.

Inequity flowing from policy change

Once the female expatriates had committed to their long-term assignment, organisational changes made to reward policy caused dissatisfaction:

"Your decision before you go is based on what the policy is. But I think it is difficult when they change the policy in the middle of anything." (Milly, Central Asia)

In Company A cost cutting efforts led to damage to the employment relationship between affected expatriates and their organisation:

“...we moved our exploration group ... to (North America) ... moving about 50 expats ... I was nothing to do with that ... but I ... got caught up in this group ... and after about three or four months they ... started to look at the bills ... and told us ... 
they were going to put us on localised type deals. For my husband this was a huge thing, because the only thing that made this move good for him was that a) it was good for my career and b) we would get paid a bit more to do it. So I had this huge family issue to deal with ... but to be perfectly honest from my perspective... that whole issue of localisation ... I didn't necessarily have a problem with it. But what I had a problem with was the way that it was implemented. And ... when you are going through these things it affects morale and it taints the way you look at the job and it taints your experience and it really doesn't make you feel really great about the company you work for to be honest. (Di, East Asia)

The female assignees in Company B pointed out that they believed that policy change always worked in the company's favour at the expense of the assignee:

"When I came I was on unaccompanied status, and at the time, the local policy said that I was entitled to $X$ dollars for housing ... and I found a place, which was above that band, and I didn't mind paying the extra myself ... Then the policy changed in that it was based on grade and I qualified for the grade where I would not have to fork out of my own pocket. So I made an application and I said, 'I see that this is now $X$ dollars at this grade, is it okay?' And they said 'no carry on paying, because this policy is effective for employees coming in at this date, the date that the policy was published, and you were employed before'. So okay, fine. However, there was inconsistent application in that the reduction of some benefits ... was applied to people that were there prior to it coming in. So where it benefited the company it applied." (Una, North Africa)

Una's comment was supported by many others interviewed in Company B as cost cutting exercises took their toll on the payment of established allowances. Reductions to 
housing allowances ("they are proposing ... capping the housing allowance ... I think we would be living in a shoebox." Susan, North Africa) and cost of living allowances were specifically highlighted as problematic ("I think it was actually unfair. The way they explained it, it is just a change in the exchange rate ... but for us and our (country) dollar is tied to the US dollar, so an exchange-rate change between the US dollar and the pound will have absolutely no bearing on us. "Val, North America). Proposed cutbacks to children's education fees for families with young children were identified by the women assignees as being potentially so serious as to jeopardise assignment extensions and future participation ("they may well vote with their feet ... you are prejudicing people now with kids under the age of $11 \ldots$ ". Susan, North Africa).

These examples demonstrate that while organisational communication of policy change focused on reducing the compensating differential between expatriates and locals to meet the organisational objective of reducing the cost of expatriation, this action did not take into account assignees' existing commitments or expectations. Pate and Scullion (2010) suggest that discontent can result from a lack of value placed on international experience. The organisations did not actively try to manage assignee expectations and so, by cutting rewards while the women were on assignment, their actions suggested devaluation of the assignees' worth. Unsurprisingly, organisational cost-cutting damaged assignees' perceptions of equity and fair treatment. It is thus crucial that upon identifying competitive pressures, organisations manage the change process effectively not only by creating and communicating the new reality but also by recognising assignees involved in the change process, articulating their contribution to organisational success and rewarding them appropriately (Kotter, 2007).

De-duplication of reward elements for co-working and dual career couples 
Another major issue raised by the female assignees concerned their perceptions of how their organisations addressed compensating differentials and engendered equity when they relocated with their spouses/partners. This affected all of the women who were part of coworking couples (both partners were working as expatriates for the same firm) and those in dual career couples (both partners were working as expatriates but for different organisations). For example, the women expatriates reported considerable dissatisfaction with how their employing organisations took account of their husband's co-working expatriate status in the calculation of reward elements, such as settling-in allowances and COLA. Thus, when a co-working couple was posted together, their firms paid one COLA and one settlingin allowance to the couple rather than one to each partner. This was regarded as unfair as it was perceived not only to reduce the couple's living standards but was also viewed as inequitable given that expatriate couples with only one working partner also received one payment ("Our standard of living is based on two incomes, and they only give it to one of us ... that annoys me." Rhoda, Australasia)

When dual career couples were posted, Companies A and B both co-ordinated the reward packages that they provided with the expatriate's partner's employing organisation. This reduced costs by de-duplicating benefits. However, the female expatriates perceived this treatment as inequitable:

"To me, it is very, very important that I get everything that my husband gets. It doesn't matter who I'm married to, it matters that I am treated equally like any other employee. I just happen to be married to another person, who is an expat. (Company A) was pretty good about giving me everything my husband gets except we don't get double allowance for our accommodation ... I asked ... 'would you at least make me whole, can you give me parity with your policy as my husband is already carrying us 
for $\$ 3000$ and can you make up the difference of what I would get if I was carrying us'." (Fiona, East Asia)

Female assignees do not expect to be treated differently from other expatriates in their firm when they relocate as part of a co-working or dual career couple. As with other reward elements reported in these findings, adjustments made in policy implementation that reduce their reward packages damage women's perceptions of equity and affect the employment relationship.

The effects of organisational transparency and communication of long-term assignment reward policy implementation on women's assignment participation are discussed in the following section. We draw upon these findings to inform our theoretical understanding, provide future research themes and suggest implications for practice.

\section{Discussion}

\section{Implications of the findings for theory building}

Female expatriates clearly exhibit concerns over organisational transparency and fairness in the provision of international assignment rewards. The compensating differentials (Rosen, 1986) applied make long-term international assignments financially attractive. Nonetheless perceptions of inequity (Adams, 1963) resulting from inadequate communications of the practicalities of policy implementation and change are articulated as feelings of disappointment, annoyance and anger. These suggest potential damage to women's psychological contracts (Rousseau, 1989) and these are translated into expressions of unwillingness to accept future assignments, refusals to extend current postings and intentions to leave. The literature makes clear that the application of compensating differentials to enhance expatriates' rewards creates negative implications for perceptions of justice within 
organisations vis-à-vis locals (Bonache, 2006). While this research does not address the views of their male expatriate colleagues, women are under-represented as expatriates and hence the need to hear their voices. And there is evidence from listening to them to support the various components of organisational justice theory (Byrne and Cropanzano, 2001; Colquitt, Greenberg and Zapata-Phelan, 2005; Hansen, Byrne and Kiersch 2013; Gilliland, Gross and Hogler, 2014). This can be taken forward to build theory to underpin expatriate compensation research and practice for women, and in respect of both sexes.

The organisational justice literature focuses on the reasonableness, or lack of it, of outcomes, procedures, and the context surrounding those procedures (Byrne and Cropanzano, 2001; Colquitt et al., 2005; Hansen et al., 2013). These aspects of organisational justice together provide the antecedents to individuals' perceptions of equity and fairness in their interactions within organisations (Gilliland et al., 2014). Consequences have been described in the form of a 'ripple effect' (Maxham, Netemeyer and Lichtenstein, 2008). If someone feels fairly treated then, in turn, they tend to treat others similarly. And the reverse may follow: perceptions of a sense of inequity or unfairness. A negative ripple can roll into unintended HR outcomes: for instance, when individuals leave an employer during or after an international assignment incurring human capital loss (Harzing and Christensen, 2004); complain about their assignments on social media sites potentially affecting the willingness of others to undertake expatriation; and commercially such as in poor customer or partner satisfaction and retention. These considerations suggest there are strategic reasons for paying attention to organisational justice in determining compensation for employees undertaking long-term international assignments and, especially in organisations changing policy focus, being mindful of their feelings "not because of who they are, but according to what they are expected, and do, to achieve" (McNulty and Aldred, 2013:3). 
Outcomes-related or 'distributive' justice (Chory and Kingsley Western, 2009; Homans, 1961) reflects an evaluation by individuals of what they receive in a given transaction compared with what others receive accounting for other factors held in common demographic characteristics and amount of work undertaken, for example. The roots of distributive justice lie in work by Adams (1963) under the rubric of equity, or inequity, of outcomes from inputs (capabilities and effort) by individuals who assess these outcomes compared to rules and referents (past experiences and/or co-workers) chosen by themselves. Procedural justice refers to the fairness of processes used to determine how outcomes are allocated; that is how decisions are made (Palaiologos, Papazekos and Panayotopoulou, 2011). At the heart of procedural justice lies: consistency of decision standards across individuals and over time; accurate, unbiased decision criteria; and providing voice or representation in decision-making (Brown, Bemmels and Barclay, 2010, drawing on Leventhal, 1980). Context related 'interactional' justice covers the way in which decisions are communicated and implemented, combining interpersonal aspects (treating people with dignity and respect) and informational aspects (providing adequate explanation for decisions) (Gilliland et al., 2014; Brown et al., 2010). There is also a moral dimension, which relates to a guiding principle that people deserve to be treated fairly, mindful of both facts and nonnegotiable values (Cugueró-Escofet and Fortin, 2014; Folger, Cropanzano and Goldman, 2005).

Expatriate reward, together with the process and contexts for setting it, represent a form of communication indicating how the expatriate is perceived relative to others, potentially feeding-back a managerial view of the value of the individual to the organisation. Feedback that is viewed negatively by the recipient may risk responses whereby an individual seeks to rebalance the relationship with an employer by holding back on performance in terms of its core task components (Chory and Kingsley Westerman, 2009; Johnson, Holladay 
and Quinones, 2009). Even where employees have been found not to go so far as to exhibit hostility towards the organisation (Fernandes and Awamleh, 2006), a sense of dissatisfaction may limit the 'organisational citizenship' aspects of performance as well as informal 'prosocial' acts benefitting organisational stakeholders (Johnson et al., 2009), and thus undermine achievement of the HR and commercial goals.

Organisations introduce policies to guard against the risk of inequitable treatment of individuals. But the act of doing so, Brown et al. (2010) argue, does not remove the possibility that employees will feel unjustly treated in any case, by having their circumstances related to a policy they regard as unfair. While recipients of the outcome of decisions on the application of policy may interpret those applications as just within the bounds of the policy, they may still regard themselves subject to inequitable treatment due to the nature of the policy itself. Policy represents an abstraction, judged in terms of how employees perceive it at a more general level of reference, whereas procedures for implementing policy focus on specific situations in which implementation occurs. For Brown et al. (2010) responses to policies depend on the decision criteria themselves (policy justice); the process to arrive at individual decisions is the focus of procedural justice assessments by those affected.

Women expatriates whose expectations are not met in having access to a reward balance sheet policy designed mindful of their priorities vis-à-vis others - for example focusing on housing representing their grade rather than single status or potentially on family assistance as suggested by Anker (2001) - may judge this as unreasonable. They may regard their voices in relation to such policy considerations as being unfairly constrained by an organisation seeking to deploy women expatriates, even if specific application of the policy itself is deemed equitable between male and female expatriates. The findings from this study also indicate women's sense of distributive inequity when expatriate compensation outcomes are perceived as failing to adhere to the balance sheet's 'keeping the individual whole' 
principle against referents defined by women expatriates themselves. This is illustrated by the effect on two-income households when two partners working on assignment do not both receive all aspects of a 'fully funded' package. Nonetheless, the outcomes of having policy elements in place which intend to avoid such negative reactions on the part of employees - in this case female expatriates - remain indeterminate. This leads to the following future research theme:

Theme 1: Perceived reward (in)equity by female expatriates is consolidated through the ways in which individuals relate themselves to others they may regard as comparators.

Outcomes also depend on individual interpretations of the factors involved in how policy decisions are made and communicated, and the impressions recipients distil from them. Procedural justice is thus compromised, for example, by creeping inequity when individuals become aware that differential expatriate packages may be the result of 'localised' negotiation, and when changes are introduced without opportunities for their voices to be heard with results always biased in the employer's favour. This leads to the following future research theme:

Theme 2: Perceived reward (in)equity by female expatriates is consolidated through their interactions with those involved in applying the policies and managing attendant processes.

Interactional justice is manifested in information transparency and explanation. For example, contextual and policy injustices apply when strictness in application combined with lack of transparency mean women's priorities may be ignored corporately to avoid the risk of opening policy to universal application. And moral values may be compromised by the 'market rates' defence when judging compensation for expatriation hardships against different points of origin. This leads to the following future research theme: 
Theme 3: Perceived reward equity is more likely to occur when female expatriates are able to access transparent and credible policy information and explanation.

Theoretical discourse, informed by compensating differentials reasoning, suggests placing an emphasis on economic exchanges in persuading women employees to undertake long-term international assignments. Drawing on organisational justice frameworks helps us to understand that the situation is complicated and that theory needs to be refined accordingly. Attention needs to be paid to intermediating considerations that may distort theoretically anticipated behaviour among women expatriates: we need to be mindful of the attitudinal shifts that may be provoked when individuals perceive how policies are applied, communicated and modified given these can provoke a sense of relative deprivation.

However, it cannot be expected that applying the same policies aiming to achieve similar outcomes, following similar procedures and approaching related interpersonal interactions in similar ways will result in common responses among women expatriates offered expatriate rewards. Intermediating factors derived from every individual set of circumstances need to be observed as these are likely to impact materially on female expatriates' reactions to compensating differential expatriate reward policies. In essence, processes and outcomes viewed as inequitable can fundamentally undermine the economic exchange and psychological contracting role of balance sheet reward policy incorporating compensating differentials intended to secure acceptance of long-term assignments among women employees.

\section{Implications for organisational practice}

Casper and Buffardi (2004) demonstrate that work-life benefits offered by organisations serve to enhance recruitment through a perceived supportive culture but that this support must be maintained post-employment to avoid psychological contract violation. Similarly, the findings from the women expatriates in this research show that organisations should not only 
ensure that the reward policy offered to international assignees fosters assignment take-up for diverse applicants but also its practical implementation maintains expatriates' expectations as the assignment progresses to avoid perceived inequity and potential psychological contract breach. Thus, international assignment reward policies need to be made available as they are a crucial factor in the expatriate participation decision. As changes to reward policy are developed, on-going communication is also required. Ideally, assignees should be involved in policy review to ensure that policy changes made do take current commitments into account. Organisations also need to explain the elements that comprise the policy so that assignees do not misunderstand their intention. As Pate and Scullion (2010) suggest, organisations should take steps to influence expatriates' expectations. This will help to reduce the likelihood of perceptions of inequity and enhance those of organisational justice.

While HR may operate a flexible approach to the interpretation of policy within guidelines (through necessity as it is impractical to require amending/rewriting it continually), it is important that the HR decision-making process and pay and benefits outcomes are transparent to recipients. Open communication is crucial (McNulty, 2014). While recognising local resource pressures and that expatriates may perform in the host country with a considerable degree of autonomy from the headquarters (Bonache and Fernández, 1997), effort is nonetheless required to resolve tensions between the headquarters' custodians, host country line managers and recipients of policy (Perkins and Daste, 2007). Local policy interpretation and provision of compensation and benefits elements in the host country must not undermine policy intention and transparency.

This study shows that the policy elements that are of the greatest importance to female expatriates in their expatriation participation decision tend to create the most dissatisfaction if their provision is considered inequitable. Employers might thus look first at the key elements desired by employees before adapting their reward programmes (Lowe, Milliman, De Cieri 
and Dowling, 2002). Identified here as being some of the elements of greatest importance to women are housing allowances, salary uplifts, and children's education. Employers could begin with these points to consider how to reduce any potential inequity in implementation. If current policy leads to unintended gendered effects for reward delivery, review could also assist in the provision of an international assignment policy structure that is more encouraging to female expatriation. For example, male expatriates are more likely to be married/partnered than women (Brookfield Global Relocation Services, 2014). Allowances based on grade (for example, housing), which should result in equitable provision, can be distorted by accompanied status, leading to the situation where women appear to be more frequently disadvantaged (because they often go solo) compared with their male colleagues (who are usually accompanied).

A further example, illustrated here, concerns the provision of allowances being deduplicated or reduced when applied to co-working and dual career couples. While HR justifies this on cost grounds (double the benefits provision is unnecessary and expensive), and therefore it is usual practice to balance out elements in the package to keep the couple 'whole' but not over-compensated financially (Oemig, 1999), action is needed to explain to assignees how allowances are structured if they inherently reflect marital/accompanied status. For example, COLA might be paid to the higher earner but be calculated taking into account family size.

The unintended gendered nature of how payments are made to dual career expatriates must be considered. Spouses can feel 'cut off' or that they have only a 'shadowed relationship' with their partner's employer (McNulty and Pember, 2014). For instance, allowances might be paid to the higher earner but this is often the man, leading to perceptions by female expatriates of being discounted or under-valued. Care is also required in the determination of allowances based on location including the use of matrix style allowances 
linked to home/host country pairings. An unintended consequence is the message that the organisation values its people differently (expatriates versus locals; and expatriates from different home locations) which can be extremely damaging to employees' sense of justice and morale (Chen, Choi and Chi, 2002; Leung, Wang and Hon, 2011). While standard formulae in policy design and implementation may hinder mobility of particular sub-sections of the expatriate talent pool and attempts to provide individualised support can have benefits in redressing any such lack of expatriate diversity (Farndale, Pai, Sparrow and Scullion, 2014), care must be taken by employers to ensure a sense of equity and justice prevails. As Haslberger and Brewster (2009: 391) point out: "Organizations need to be more aware of the psychological contract's role in international assignments and manage it for positive consequences".

\section{Research limitations and call for further research}

This research examined long-term international assignment reward designed and delivered using balance sheet methodology, set in the oil and gas industry in two medium-sized exploration and production organisations. Further suitably theoretically framed research, potentially linked to organisational justice, is needed to examine the effects of different reward methodologies in other sectors and in organisations of different sizes on women's expatriation decisions. This study examined women's views on policy transparency, equity and change from the perspective of those who had accepted long-term international assignments having being deployed on policy terms and conditions developed by Western headquartered firms. It would be valuable to hear from women who have rejected assignments to learn of the effects of reward provision on their decisions. We know little about expatriate compensation policy developed in a non-Western context and the cultural implications of expatriate rewards (Gomez-Mejia and Welbourne, 1991) or about the effects of nationality on expatriates' attitudes towards expatriate rewards (Bonache, 2006). Hence, it 
would also be useful to examine the effects of policy design reflecting firms headquartered in non-Western societal cultures on female expatriation and to learn about how expatriates from non-traditional sending locations view reward policy. Cerdin and Brewster (2014) draw attention to potentially differing objectives between short-term financial rewards and longerterm careers in the context of expatriation and talent management. While this study focuses on the effects of reward policy and practice on women's assignment participation, further research that links these issues into organisations' talent management activities would be most valuable.

A cross-sectional research design was employed. Given practitioner surveys such as those presented by expatriate consultancies such as Brookfield Global Relocation Services (2014, 2015) and Cartus (2014) indicate emphasis on cost control and erosion of policy content for long-term assignments, rigorous longitudinal research that explores how policy element reduction and removal influence female expatriation would be valuable. In addition, research into the effects of alternatives to the balance sheet, such as where expatriates receive local salaries plus limited benefits ('local-plus') which are becoming increasingly of interest to organisations (McNulty and Aldred, 2013), would also be helpful. Further research could also help us to evaluate the relevance of this pay methodology to long-term expatriation visà-vis alternatives such as headquarters approaches (Dwyer, 1999) and 'transpatriate' (global) compensation (Phillips and Fox, 2003).

Future research into reward arrangements for alternative assignments types (such as short-term international assignments, commuting and rotational working) would also be valuable in the context of women's expatriation to understand the influence of reward in women's decisions to undertake such mobility lengths and patterns. As international travel becomes "the 'backbone' of a global career" (Lirio, 2014:169) so investigation into reward for global business travellers would also merit research attention. 
Comparative research that examines men's and women's opinions on the importance of various balance sheet elements might highlight differentials in policy provision that could lead to the development of different approaches to expatriate reward for men and women with implications for increasing gender diversity. This has the potential to be especially valuable in masculine industries such as oil and gas, mining and engineering. In addition, the literature reports an increase in the proportion of female-led expatriate couples (Salamin and Hanappi, 2014); thus the influence of reward policy on their decisions to undertake expatriation would also be valuable.

\section{Conclusion}

This study finds that organisational transparency and clear communication of international assignment rewards is crucial if women are to remain satisfied with their expatriate terms and conditions and undertake future expatriate roles. It adds to our knowledge gleaned from other studies that help to explain low female expatriate representation by highlighting perceived reward inequities that discourage women's expatriation. Specifically, it highlights perceived inequitable treatment linked to grade and family status experienced by single women, reductions in reward applied to dual career and co-working women, cutbacks in family support received by mothers and perceived inequity in salary and allowances received by women linked to home/host country pairings. Careful consideration is therefore needed going forward to design and implement reward policies that help to foster a climate of organisational justice that encourages female expatriation rather than one which creates unintended gendered outcomes to the potential detriment of increasing expatriate gender diversity. 


\section{References}

Adams, S.J. (1963), “Towards an understanding of inequity”, Journal of Abnormal and Social Psychology, Vol. 67, No. 5, pp. 422-436.

Adler, N.J. (1984), “Women in international management: where are they?”, California Management Review, Vol. 26, No. 4, pp. 78-89.

Adler, N.J. (1987), "Pacific basin managers: a gaijin, not a woman”, Human Resource Management, Vol. 26, No. 2, pp. 169-191.

Adler, N.J. and Bartholomew, S. (1992), "Managing globally competent people”, Academy of Management Executive, Vol. 6, No. 3, pp. 52-65.

Altman, Y. and Shortland, S. (2008), "Women and international assignments: taking stock - a 25-year review”, Human Resource Management, Vol. 47, No. 2, pp. 199-216.

Anker, R. (2001), “Theories of occupational segregation by sex: an overview”, in Loutfi, M.F. (Ed.), Women, Gender and Work: What is Equality and How Do We Get There? International Labour Organization, Geneva, pp. 129-155.

Benson, G.S. and Pattie, M. (2008), "Is expatriation good for my career? The impact of expatriate assignments on perceived and actual career outcomes", The International Journal of Human Resource Management, Vol. 19, No. 9, pp. 1636-1653.

Bonache, J. (2006), "The compensation of expatriates: a review and a future research agenda”, in Stahl, G.K. and Björkman, I. (Eds.), Handbook of Research in International Human Resource Management, Edward Elgar, Cheltenham, pp. 158-175. 
Bonache, J. and Fernández, Z. (1997), “Expatriate compensation and its link to the subsidiary strategic role: a theoretical analysis", The International Journal of Human Resource Management, Vol. 8, No. 4, pp. 457-475.

Bonache, J., Sanchez, J.I. and Zárraga-Oberty, C. (2009), “The interaction of expatriate pay differential and expatriate inputs on host country nationals' pay unfairness", The International Journal of Human Resource Management, Vol. 20, No. 10, pp. 2135-2149.

Borstorff, P.C., Harris, S.G., Feild, H.S. and Giles, W.F. (1997), “Who'll go? A review of factors associated with employee willingness to work overseas", Human Resource Planning, Vol. 20, No. 3, pp. 29-40.

Brookfield Global Relocation Services. (2009), “International Mobility: Impact of the Current Economic Climate, Brookfield Global Relocation Services, Chicago, IL.

Brookfield Global Relocation Services. (2014), Global Relocation Trends: 2014 Survey Report, Brookfield Global Relocation Services, Chicago, IL.

Brookfield Global Relocation Services. (2015), Mindful Mobility: 2015Global Relocation Trends, Brookfield Global Relocation Services, Chicago, IL.

Brown, G., Bemmels, B. and Barclay, L.J. (2010), “The importance of policy in perceptions of organizational justice", Human Relations, Vol. 63, No. 10, pp. 1587-1609.

Byrne, Z.S. and Cropanzano, R. (2001), "History of organizational justice: the founders speak", in Cropanzano, R. (Ed.), Justice in the Workplace (Volume II): From Theory to Practice, Lawrence Erlbaum Associates, Mahwah, NJ, pp. 3-26. 
Caligiuri, P.M. and Colakoglu, S. (2007), “A strategic contingency approach to expatriate assignment management", Human Resource Management Journal, Vol. 17, No. 4, pp. 393410.

Carpenter, M.A, Sanders, W.G. and Gregersen, H.B. (2001), "Building human capital with organizational context: the impact of international assignment experience on multinational firm performance and CEO pay", Academy of Management Journal, Vol. 44, No. 3, pp.493511.

Cartus. (2014), Global Mobility Policy and Practices 2014 Survey Report: Trends in Global Relocation, Cartus, Danbury, CT.

Casper, W.J. and Buffardi, L.C. (2004), "Work-life benefits and job pursuit intentions: the role of anticipated organizational support", Journal of Vocational Behavior, Vol. 65, No. 3, pp. 391-410.

Cerdin, J.-L., and Brewster, C. (2014), “Talent management and expatriation: bridging two stream of research and practice”, Journal of World Business, Vol. 49, No. 2, pp. 245-252.

Chen, C.C., Choi, J. and Chi, S-C. (2002), "Making justice sense of local-expatriate compensation disparity: mitigation by local referents, ideological explanations, and interpersonal sensitivity in China-foreign joint ventures", Academy of Management Journal, Vol. 45, No. 4, pp. 807-817.

Chesters, A. (1998), "Reward in an international context", Journal of Professional HRM, Vol. 10, January, pp. 24-30.

Chory, R.M. and Kingsley Westerman, C.Y. (2009), "Feedback and fairness: the relationship between negative performance feedback and organizational justice", Western Journal of Communication, Vol. 73, No. 2, pp. 157-181. 
Cole, N. and McNulty, Y. (2011), "Why do female expatriates "fit-in" better than males? An analysis of self-transcendence and socio-cultural adjustment”, Cross Cultural Management: An International Journal, Vol. 18, No. 2, pp.144-164.

Collis, J. and Hussey, R. (2009), Business Research: A Practical Guide for Undergraduate and Postgraduate Students, Palgrave Macmillan, Basingstoke.

Colquitt, J.A., Greenberg, J. and Zapata-Phelan, C.P. (2005), "What is organizational justice? A historical overview", in Greenberg, J. and Colquitt, J.A. (Eds.), Handbook of Organizational Justice, Lawrence Erlbaum Associates, Mahwah, NJ, pp. 3-56.

Cugueró-Escofet, N. and Fortin, M. (2014), “One justice or two? A model of reconciliation of normative justice theories and empirical research on organizational justice”, Journal of Business Ethics, Vol. 124, No. 3, pp. 435-451.

Dallalfar, A. and Movahedi, S. (1996) "Women in multinational corporations: old myths, new constructions and some deconstruction”, Organization, Vol. 3, No. 4, pp. 546-559.

Dickmann, M. and Baruch, Y. (2011), Global Careers, Routledge, Abingdon.

Dickmann, M., Doherty, N., Mills, T. and Brewster, C. (2008), "Why do they go? Individual and corporate perspectives on the factors influencing the decision to accept an international assignment", The International Journal of Human Resource Management, Vol. 19, No. 4, pp. $731-751$.

Dowling, P.J. and Welch, D.E. (2004), International Human Resource Management: Managing People in a Multinational Context, Thomson, London.

Dwyer, T.D. (1999), “Trends in global compensation”, Compensation \& Benefits Review, Vol. 31, No. 4, pp. 48-53. 
Eisenhardt, K.M. (1989), “Building theories from case study research”, Academy of Management Review, Vol. 14, No. 4, pp. 532-550.

Farndale, E., Pai, A., Sparrow, P. and Scullion, H. (2014), "Balancing individual and organizational goals in global talent management: a mutual-benefits perspective", Journal of World Business, Vol. 49, No. 2, pp. 204-214.

Fernandes, C. and Awamleh, R. (2006), "Impact of organisational justice in an expatriate work environment”, Management Research News, Vol. 29, No. 11, pp. 701-712.

Folger, R., Cropanzano, R. and Goldman, B. (2005), "What is the relationship between justice and morality?", in Greenberg. J. and Colquitt, J.A. (Eds.), Handbook of Organizational Justice, Lawrence Erlbaum Associates, Mahwah, NJ, pp. 215-246.

Gilliland, S.W., Gross, M.A. and Hogler, R.L. (2014), "Is organizational justice the new industrial relations? A debate on individual versus collective underpinnings of justice", Negotiation and Conflict Management Research, Vol. 7, No. 3, pp. 155-172.

Gomez-Mejia, L.R. and Welbourne, T. (1991), "Compensation strategies in a global context", Human Resource Planning, Vol. 14, No. 1, pp. 29-41.

Gripenberg, P., Niemistö, C. and Alapeteri, C. (2013), “Ask us equally if we want to go", Journal of Global Mobility, Vol. 1, No. 3, pp. 287-311.

Guest, D.E. and Conway, N. (2002), “Communicating the psychological contract: an employer perspective”, Human Resource Management Journal, Vol. 12, No. 2, pp. 22-38.

Guzzo, R.A., Noonan, K.A. and Elron, E. (1994), "Expatriate managers and the psychological contract”, Journal of Applied Psychology, Vol. 79, No. 4, pp. 617-626. 
Hansen, A.M., Byrne, Z.S. and Kiersch, C.E. (2013), "Development and validation of an abridged measure of organizational justice", The Journal of Psychology, Vol. 147, No. 3, pp. 217-244.

Harrison, E.C. and Michailova, S. (2012) "Working in the Middle East: Western female expatriates' experiences in the United Arab Emirates", The International Journal of Human Resource Management, Vol. 23, No. 4, pp. 625-644.

Harvey, M. and Moeller, M. (2009), “Expatriate managers: a historical review”, International Journal of Management Reviews, Vol. 11, No. 3, pp. 275-296.

Harzing, A-W. and Christensen, C. (2004), "Expatriate failure: time to abandon the concept?", Career Development International, Vol. 9, No. 7, pp. 616-626.

Haslberger, A. and Brewster, C. (2009), “Capital gains: expatriate adjustment and the psychological contract in international careers", Human Resource Management, Vol. 48, No. 3, pp. 379-397.

Hippler, T. (2009), “Why do they go? Empirical evidence of employees' motives for seeking or accepting relocation”, The International Journal of Human Resource Management, Vol. 20, No. 6, pp. 1381-1401.

Hocking, J.B., Brown, M. and Harzing, A.-W. (2004), “A knowledge transfer perspective of strategic assignment purposes and their path-dependent outcomes", The International Journal of Human Resource Management, Vol. 15, No. 3, pp. 565-586.

Homans, G.C. (1961), Social Behavior: Its Elementary Forms, Harcourt, Brace and World, New York, NY. 
Hutchings, K., Lirio, P. and Metcalfe, B.D. (2012), “Gender, globalisation and development: a re-evaluation of the nature of women's global work", The International Journal of Human Resource Management, Vol. 23, No. 9, pp. 1763-1787.

IDS. (2002), International Assignments, IDS Studies, No. 728, May, Incomes Data Services Ltd, London.

Johnson, M.E. (2015), “Testing times for the global oil and gas sector”, Re:Locate, Spring, pp. 6-9.

Johnson, S.K., Holladay, C.L. and Quinones, M.A. (2009), “Organizational citizenship behavior in performance evaluations: distributive justice or injustice?", Journal of Business and Psychology, Vol. 24, No. 4, pp. 409-418.

King, N. (2004), "Using templates in the thematic analysis of text", in Cassell C. and Symon, G. (Eds.), Essential Guide to Qualitative Methods in Organizational Research, Sage, London, pp. 256-270.

Kotter, J.P. (2007), “Leading change. Why transformation efforts fail”, Harvard Business Review, Vol. 85, No. 1, pp. 96-103.

Leventhal, G.S. (1980), "What should be done with equity theory? New approaches to the study of fairness in social relationships", in Gergen, K., Greenberg, M. and Willis, R. (Eds.), Social Exchange, Plenum Press, New York, NY, pp. 27-55.

Leung, K., Wang, Z. and Hon, A.H.Y. (2011), "Moderating effects on the compensation gap between locals and expatriates in China: a multi-level analysis", Journal of International Management, Vol. 17, No. 1, pp. 54-67. 
Lirio, P. (2014), “Taming travel for work-life balance in global careers”, Journal of Global Mobility, Vol. 2, No. 2, pp. 160-182.

Lowe, K.B., Milliman, J., De Cieri, H. and Dowling, P.J. (2002), “International compensation practices: a ten-country comparative analysis", Human Resource Management, Vol. 41, No. 1, pp. 45-66.

Markus, U. (2015), Oil and Gas: The Business and Politics of Energy, Palgrave, London.

Maxham, J.G., Netemeyer, R.G. and Lichtenstein, D.R. (2008), “The retail value chain:

linking employee perceptions to employee performance, customer evaluations, and store performance”, Marketing Science, Vol. 27, No. 2, pp. 147-167.

McNulty, Y. (2014), “Modern expatriation through the lens of global careers, psychological contracts, and individual return on investment”, Global Business and Organizational Excellence, Vol. 33, No. 3, pp. 6-22.

McNulty, Y. and Aldred, G. (2013), "Local plus: winning the compensation battle but losing the talent war", Strategic Advisor, Vol. 4, No. 9, pp. 1-4.

McNulty Y. and Brice, J. (2014), "Linking global mobility to global talent management", available at: http://www.expatresearch.com/files/8913/9951/3200/MSI_White_Paper_GTM_May_2014.pdf (accessed 31 March 2015).

McNulty, Y., De Cieri H. and Hutchings, K. (2013), "Expatriate return on investment in the Asia Pacific: an empirical study of individual ROI versus corporate ROI", Journal of World Business, Vol. 48, No. 2, pp. 209-221. 
McNulty Y. and Pember, J. (2014), “Delivering effective relocation family support”, available at: http://www.expatresearch.com/files/9714/1679/2907/McNulty_Pember_2014AussieOS Delivering_Effective Relocation_Family_Support.pdf (accessed 31 March 2015).

Muir, M., Wallace, M. and McMurray, D. (2014), "Women on the move: the self-initiated expatriate in China", Journal of Global Mobility, Vol. 2. No. 2, pp. 234-254.

Oemig, D.R.A. (1999), “When you say “we'll keep you whole,” do you mean it?”, Compensation \& Benefits Review, Vol. 31, No. 4, pp. 40-47.

ORC Worldwide. (2007), 2006 Worldwide Survey of International Assignment Policies and Practices, ORC Worldwide, New York, NY.

Orser, B. and Leck, J. (2010), “Gender influences on career success outcomes”, Gender in Management: An International Journal, Vol. 25, No. 5, pp. 386-407.

Palaiologos, A., Papazekos, P. and Panayotopoulou, L. (2011), “Organizational justice and employee satisfaction in performance appraisal”, Journal of European Industrial Training, Vol. 35, No. 8, pp. 826-840.

Pate, J. and Scullion, H. (2010), “The changing nature of the traditional expatriate psychological contract”, Employee Relations, Vol. 32, No. 1, pp. 56-73.

Perkins, S.J. and Daste, R. (2007), "Pluralistic tensions in expatriating managers", Journal of European Industrial Training, Vol. 31, No. 7, pp. 550-569.

Perkins, S.J. and Shortland, S.M. (2006), Strategic International Human Resource Management: choices and Consequences in Multinational People Management, Kogan Page, London. 
Perkins, S.J. and White, G. (2011), Reward Management: Alternatives, Consequences and Contexts, CIPD, London.

PricewaterhouseCoopers/Cranfield. (2006), Measuring the Value of International Assignments, PricewaterhouseCoopers LLP, London.

Phillips, L. and Fox, M.A. (2003), “Compensation strategy in transnational corporations”, Management Decision, Vol. 41, No. 5, pp. 465-476.

Richardson, J., McKenna, S. and Dickie, C. (2014), ““They always look at you a bit oddly”: women developing career capital through international mobility in the mining industry", in Hutchings K. and Michailova, S. (Eds.), Research Handbook on Women in International Management, Edward Elgar, Cheltenham, pp. 367-394.

Rosen, S. (1986), "The theory of equalizing differences", in Ashenfelter O. and Layard, R. (Eds.), Handbook of Labor Economics, Volume 1, Elsevier Science Publishers B.V., Amsterdam, pp. 641-692.

Rousseau, D.M. (1989), "Psychological and implied contracts in organizations", Employee Responsibilities and Rights Journal, Vol. 2, No. 2, pp. 121-139.

Rousseau, D.M. (1995), Psychological Contracts in Organizations: Understanding Written and Unwritten Agreements, Sage, Thousand Oaks, CA.

Salamin, X. and Hanappi, D. (2014), "Women and international assignments", Journal of Global Mobility, Vol. 2, No. 3, pp. 343-374.

Saunders, M., Lewis, P. and Thornhill, A. (2009), Research Methods for Business Students, Pearson Education, Harlow. 
Scott, D., Brown, M., Shields, J., Long, R., Antoni, C.H., Beck-Krala, E.J., Lucia-

Casademunt, A.M. and Perkins, S.J. (2015), “A global study of pay preferences and employee characteristics", Compensation \& Benefits Review, Vol. 47, No. 2, pp. 60-70.

Shortland, S. (2014a), "Women expatriates: a research history”, in Hutchings K. and Michailova, S. (Eds.), Research Handbook on Women in International Management, Edward Elgar, Cheltenham, pp. 18-44.

Shortland, S. (2014b), "Role models: expatriate gender diversity pipeline or pipe-dream?", Career Development International, Vol. 19, No. 5, pp. 572-594.

Shortland, S. (2015), “The purpose of expatriation: why women undertake international assignments", Human Resource Management, in press.

Sims, R.H. and Schraeder, M. (2005), "Expatriate compensation: an exploratory review of salient contextual factors and common practices", Career Development International, Vol. 10, No. 2, pp. 98-108.

Suutari, V. and Tornikoski, C. (2001), “The challenge of expatriate compensation: the sources of satisfaction and dissatisfaction among expatriates", The International Journal of Human Resource Management, Vol. 12, No. 3, pp. 389-404.

Suutari, V., Tornikoski, C. and Mäkelä, L. (2012), “Career decision making of global careerists", The International Journal of Human Resource Management, Vol. 23, No. 16, pp. $3455-3478$.

Tarique, I., Briscoe, D. and Schuler, R. (2016), International Human Resource Management: Policies and Practices for Multinational Enterprises, Routledge, New York. 
Tharenou, P. (2009), "Self-initiated international careers: gender differences and career outcomes", in Baugh, S.G and Sullivan, S.E. (Eds.), Maintaining Focus, Energy, and Options over the Career, Information Age, Charlotte, pp. 198-226.

Tharenou, P. (2014), "Self-initiated expatriation by women: does it help to overcome the glass ceiling?”, in Hutchings K. and Michailova, S. (Eds.), Research Handbook on Women in International Management, Edward Elgar, Cheltenham, pp. 304-331.

Thomas, D.C, Lazarova, M.B. and Inkson, K. (2005), "Global careers: new phenomenon or new perspectives?”, Journal of World Business, Vol. 40, No. 4, pp.340-347.

Tornikoski, C. (2011a), "Fostering expatriate affective commitment: a total reward perspective", Cross Cultural Management: An International Journal, Vol. 18, No. 2, pp. 214235.

Tornikoski, C. (2011b), "Expatriate compensation: a theoretical approach", in Antoni, C.H., Baeten, X., Lucas, R., Perkins, S. and Vartiainen, M. (Eds.), Pay and Reward Systems in Organizations - Theoretical Approaches and Empirical Outcomes, Pabst Science Publishers, Lengerich, pp. 38-67.

Tung, R.L. (2004), “Female expatriates: the model global manager?”, Organizational Dynamics, Vol. 33, No. 3, pp. 243-253.

Varma, A., Toh, S.M. and Budhwar, P. (2006), “A new perspective on the female expatriate experience: the role of host country national categorization", Journal of World Business, Vol. 41, No. 2, pp.112-120.

Warneke, D. and Schneider, M. (2011), "Expatriate compensation packages: what do employees prefer?", Cross Cultural Management: An International Journal, Vol. 18, No. 2, pp. 236-256. 
1

2

3

4

5

6

7

8

9

10

11

12

13

14

15

16

17

18

19

20

21

22

23

24

25

26

27

28

29

30

31

32

33

34

35

36

37

38

39

40

41

42

43

44

45

46

47

48

49

50

51

52

53

54

55

56

57

58

59

60
Welch, D. (1994), "Determinants of international human resource management approaches and activities: a suggested framework", Journal of Management Studies, Vol. 31, No. 2, pp. 139-164.

Yin, R.K. (2009), Case Study Research: Design and Methods, Sage, Thousand Oaks, CA. 
Table 1: Profile of long-term assignees interviewed

\begin{tabular}{lllll}
\hline $\begin{array}{c}\text { Pseudonym and } \\
\text { company }\end{array}$ & \multicolumn{1}{c}{ Host region } & Home region & Marital status & $\begin{array}{c}\text { Accompanying } \\
\text { partner/children }\end{array}$ \\
\hline Company A & Central Asia & North America & Divorced/widowed & No \\
Babs & East Asia & Western Europe & Married & Yes/1 \\
Abby & East Asia & Western Europe & Married & Yes/1 \\
Di & East Asia & North America & Married & Yes \\
Fiona & North America & East Asia & Single & No \\
Gina & Western Europe & East Asia & Single & No \\
Esther & Western Europe & North America & Divorced/widowed & No \\
Harriet & & & & No \\
Company B & Australasia & Western Europe & Partnered & Yes \\
Linda & Australasia & Western Europe & Married & No \\
Olive & Australasia & Western Europe & Partnered & Yes/3 \\
Rhoda & Caribbean & Western Europe & Married & Yes \\
Izzy & Central Asia & Western Europe & Married & No \\
Milly & Central Asia & Western Europe & Married & Yes/2 \\
Yvonne & East Asia & Western Europe & Married & Yes \\
Wanda & Middle East & Western Europe & Married & Yes/1 \\
Nina & North Africa & Western Europe & Married & Yes/1 \\
Susan & North Africa & Western Europe & Married & Yes/1 \\
Una & North America & Caribbean & Married & Yes \\
Val & West Africa & Australasia & Married & No \\
Karen & West Africa & Caribbean & Single & Yes/1 \\
Xanthe & Western Europe & Western Europe & Married & \\
Polly & & & &
\end{tabular}


Table 2: Long-term assignment policy components

\begin{tabular}{|c|c|c|c|}
\hline \multirow[b]{2}{*}{ Policy element } & \multicolumn{2}{|c|}{ Company A } & \multirow{2}{*}{$\begin{array}{l}\text { Company B } \\
\text { All destinations }\end{array}$} \\
\hline & Europe \& North America & Other destinations & \\
\hline \multicolumn{4}{|l|}{ Remuneration } \\
\hline Salary, pension, vacation entitlement & Home-based & Home-based & Home-based \\
\hline Incentive scheme & $\checkmark$ & $\checkmark$ & \\
\hline Cost of Living Allowance (COLA) & $\checkmark$ & $\checkmark$ & $\checkmark$ \\
\hline Per diems & $\checkmark$ & $\checkmark$ & \\
\hline Foreign service premium (FSP) & & $\checkmark$ & $\checkmark$ \\
\hline Settling-in allowance & $\checkmark$ & $\checkmark$ & $\checkmark$ \\
\hline Peer equity allowance & & & Considered \\
\hline \multicolumn{4}{|l|}{ Housing and associated costs } \\
\hline Pre-assignment trip & $\checkmark$ & $\checkmark$ & $\checkmark$ \\
\hline Temporary accommodation & $\checkmark$ & $\checkmark$ & $\checkmark$ \\
\hline Accommodation/housing allowance & $\checkmark$ & $\checkmark$ & $\checkmark$ \\
\hline Shipment of household goods & $\checkmark$ & $\checkmark$ & $\checkmark$ \\
\hline Utility/telephone costs & $\checkmark$ & $\checkmark$ & $\checkmark$ \\
\hline \multicolumn{4}{|l|}{ Travel, local transport and leave } \\
\hline Transport to and from host location & $\checkmark$ & $\checkmark$ & $\checkmark$ \\
\hline Home leave & $\checkmark$ & $\checkmark$ & $\checkmark$ \\
\hline Home leave travel costs & $\checkmark$ & $\checkmark$ & $\checkmark$ \\
\hline Rest and relaxation breaks & & $\checkmark$ & Certain locations \\
\hline Change of scenery allowance & & & Certain locations \\
\hline Car & $\checkmark$ & $\checkmark$ & $\checkmark$ \\
\hline Driver & & $\checkmark$ & Certain locations \\
\hline Driving tuition & $\checkmark$ & $\checkmark$ & $\checkmark$ \\
\hline \multicolumn{4}{|l|}{ Family and health issues } \\
\hline Dual career/partner allowance & $\checkmark$ & $\checkmark$ & $\checkmark$ \\
\hline Education allowance & $\checkmark$ & $\checkmark$ & $\checkmark$ \\
\hline Medical insurance & $\checkmark$ & $\checkmark$ & $\checkmark$ \\
\hline Pregnancy support/maternity & Exceptional circumstances & $\checkmark$ & $\checkmark$ \\
\hline Emergency evacuation & $\checkmark$ & $\checkmark$ & $\checkmark$ \\
\hline \multicolumn{4}{|l|}{ Miscellaneous } \\
\hline Security guard & & & Certain locations \\
\hline Club membership costs & & $\checkmark$ & $\checkmark$ \\
\hline Work permit/visa expenses & $\checkmark$ & $\checkmark$ & $\checkmark$ \\
\hline
\end{tabular}




\section{Appendix: Semi-structured interview schedules}

Women assignees' interview schedule

1. Did the expatriation process work well for you? Explain.

- What role did the International Assignments (IA) team play?

- What access did you have to policy information to help guide your decisionmaking?

2. What level of importance would you place on the various elements in the IA policy in supporting your decision to go on your long-term assignment? What do you see as the key elements - the 'make or break' factors without which you would not go?

3. If applicable, how have the following helped you to undertake your IA(s):

- Spouse/partner support?

- Support for children?

- Pregnancy/maternity/parental leave support?

- Social/family support on repatriation?

4. Which aspects of the IA policy have been particularly helpful in supporting your participation? Explain.

- Have there been any changes to it that have been helpful? If yes, explain.

International Assignments (IA) HR staff interview schedule

1. Are your policies strictly applied? If applied loosely, who has benefited and how? Examples.

2. Key changes/developments in your international relocation policy within the last 5 years? When were they? Why were they implemented? 